\title{
EARLY-ONSET PARKINSON'S DISEASE AND DEPRESSION
}

\author{
Délcio Bertucci Filho', Hélio A.G. Teive², Lineu C. Werneck²
}

\begin{abstract}
Patients with Parkinson's disease (PD) in whom symptoms start before the age of 45 years (EOPD) present different clinical characteristics from those with the late-onset form of the disease. The incidence of depression is believed to be greater in patients with EOPD than with the late-onset form of the disease, although there is no risk factor or marker for depression in patients with PD. We studied 45 patients with EOPD to define the frequency of depression and to identify possible differences between the groups with and without depression. Depression was diagnosed in 16 (35.5\%) of the patients, a higher incidence than in the population at large but similar to the figure for late-onset Parkinson disease; 8 $(50 \%)$ of the patients had mild depression, $4(25 \%)$ moderate depression and $4(25 \%)$ were in remission. There was no relationship between depression and any of the clinical characteristics of the disease, although the EOPD patients with depression presented earlier levodopa-related complications and were more affected on the Hoehn-Yahr, UPDRS and Schwab-England scales.
\end{abstract}

KEY WORDS: Parkinson's disease, early-onset Parkinson's disease, depression.

\section{Doença de Parkinson de início precoce e depressão}

RESUMO - Os pacientes com doença de Parkinson (DP) cujo início dos sintomas ocorre até os 45 anos (DPIP), apresentam características clínicas que a diferem da doença de início tardio. Estudos têm sugerido que pacientes com DPIP têm maior incidência de depressão quando comparados aos de início tardio, mas sem definição de algum marcador específico da doença para depressão. Estudamos 45 pacientes com DPIP, para definir a freqüência da depressão e verificar possíveis diferenças entre os grupos com e sem depressão. A depressão foi diagnosticada em $16(35.5 \%)$ pacientes estando acima da média da população geral, porém semelhante aos índices relatados pelos estudos de pacientes com DP de início tardio; 8 (50\%) pacientes tinham depressão leve, $4(25 \%)$ moderada e $4(25 \%)$ estavam em remissão.Não houve relação da depressão com nenhuma das características clínicas da doença, embora apresentem complicações mais precoces da levodopaterapia, e sejam mais afetados nas escalas de Hoehn-Yahr, UPDRS e Schwab-England.

PALAVRAS-CHAVE: doença de Parkinson, doença de Parkinson de início precoce, depressão.

Parkinson's disease (PD) is the second most common neurodegenerative disease and affects 1 to $2 \%$ of the population over 65 years of age ${ }^{1}$. Patients who develop the clinical manifestations of PD at an earlier age are called early-onset PD (EOPD) and represent 5 to $10 \%$ of the total2. The cut-off age defined by the majority of authors has traditionally been 40 years ${ }^{3,4}$, which is approximately two standard deviations below the average age of all patients ${ }^{5}$. There is a subgroup of these patients in whom symptoms start before the age of 21 years; this form of the disease is called juvenile-onset Parkinson's disease ${ }^{4}$. A number of recent studies, however, have shown genetic mutations in a large proportion of patients with EOPD, and a cut-off age of $45^{6}$ or $50^{7}$ years has been used. Although EOPD has been considered as the lower limit of the age range for presenting PD, differences in the clinical characteristics, progression of the disease, latency period for the appearance of levodopa-related complications and prognosis suggest that there are two subtypes of the disease ${ }^{8-10}$.

The incidence of depression in EOPD is believed to be greater than in the late-onset form of the disease $^{11}$. EOPD reduces patient's quality of life independently of motor symptoms, and there is evidence that the condition is underdiagnosed and undertreated $^{12,13}$. The etiology of depression in PD is complex and probably includes biological and external factors. Studies suggest that in addition to the dopaminergic systems, the serotoninergic, noradrenergic and

Movement Disorders Unit, Neurology Service, Hospital de Clínicas, Universidade Federal do Paraná, Curitiba PR, Brazil: ${ }^{1}$ MD; ${ }^{2} \mathrm{MD}, \mathrm{PhD}$.

Received 29 May 2006, received in final form 24 August 2006. Accepted 11 October 2006.

Dr. Hélio A.G. Teive - Hospital de Clínicas da Universidade Federal do Paraná - Rua General Carneiro 181 / $12^{\circ}$ andar - $80060-900$ Curitiba PR - Brasil. E-mail: hagteive@mps.com.br 
cholinergic systems are also affected in PD and that they may contribute to cognitive and behavioral dysfunction in these patients. This would explain the lack of response of nonmotor symptoms to dopaminergic therapy ${ }^{14}$. There is a greater risk of depression in patients with PD compared with patients of other chronic diseases that cause a similar degree of disability, and it has been hypothesized that depression may be a consequence of progressive brain damage ${ }^{15}$. Studies have indicated that depression in PD is associated with rapid cognitive and motor degeneration, suggesting that it may be a marker for a more extensive lesion in the brain stem ${ }^{16}$.

In this study we aimed to define the frequency of depression in patients with EOPD and to identify possible differences between the groups with and without depression.

\section{METHOD}

Patients diagnosed with EOPD according to the following criteria were studied.

Inclusion criteria - 1) diagnosis of idiopathic PD (IPD) based on the presence of at least two of the following signs or symptoms: bradykinesia, tremor, muscular rigidity, and postural instability; 2 ) good response to levodopa treatment (>30\%); 3) progressive disease; 4 ) the absence of clinical signs characteristic of other alternative diagnoses; 5 ) the absence of significant early cognitive change; 6 ) the absence of a known etiological factor for parkinsonism; 7) the onset of symptoms before the age of forty-five years ${ }^{6,17}$.

Exclusion criteria - 1) the use of neuroleptic agents or dopaminergic blockers in the previous six months; 2) cerebral ischemia; 3) encephalitis; 4) intoxication with a substance known to cause parkinsonism; 5) a family history of Wilson's disease or Huntington's disease; 6) a congenital disease; 7) the presence of supranuclear ophthalmoparesis, long tract signs, ataxia, apraxias, alien limb sign, earlyonset dementia, severe postural instability (until the first year after the start of the symptoms), psychosis unrelated to levodopa and Kayser-Fleischer ring; 8) computerized brain tomography and/or encephalic magnetic resonance imaging suggestive of hydrocephaly, vascular or other types of lesions in the basal nuclei, reduced serum ceruloplasmin levels, the presence of acanthocytes in the hemogram and abnormal VDRL.

Patients were considered to have major depression if they had 5 or more of the 9 symptoms of the criteria of the "Diagnostic and Statistical Manual of Mental Disorders $4^{\text {th }}$ Edition (DSM-IV)"; one of these symptoms had to include anhedonia or depressed mood for at least 2 weeks ${ }^{18}$. We used the Hamilton scale with 17 items to quantify the severity of the depression ${ }^{19}$. Scores below 8 were considered to indicate depression in remission, between 8 and 18 mild depression, between 18 and 24 moderate depression, and above 24 severe depression. The DSM-IV and Mini Mental State Examination (MMSE) were used as criteria to diagnose dementia ${ }^{20}$. MMSE cut-off levels for diagnosing

Table 1. Scores for all the items on the Hamilton scale.

\begin{tabular}{lcc}
\hline Item on the Hamilton scale & $\begin{array}{c}\text { No. of patients } \\
\text { who scored in } \\
\text { each item }\end{array}$ & $\begin{array}{c}\text { Percentage (\%) of points scored in } \\
\text { each item in relation to the maximum } \\
\text { possible number of points }\end{array}$ \\
\hline 1.Mood & 16 & 37.5 \\
2.Feeling of guilt & 4 & 7.81 \\
3.Suicide & 3 & 10.94 \\
4.Initial insomnia & 10 & 50 \\
5.Middle insomnia & 11 & 50 \\
6.Terminal insomnia & 12 & 40.62 \\
7.Work and activities & 16 & 51.36 \\
8.Motor delay & 13 & 26.56 \\
9.Motor agitation & 7 & 10.94 \\
10.Psychic anxiety & 13 & 35.94 \\
11.Somatic anxiety & 11 & 21.87 \\
12.Gastrointestinal somatic symptoms & 4 & 15.62 \\
13.General somatic symptoms & 12 & 43.75 \\
14.Genital symptoms & 7 & 25 \\
15.Hypochondriasis & 1 & 1.56 \\
16.Weight loss & 3 & 10.42 \\
17.Insight & 1 & 3.12 \\
\hline
\end{tabular}


Table 2. Clinical and epidemiological characteristics of 45 cases of early-onset Parkinson's disease at evaluation.

\begin{tabular}{|c|c|c|c|c|}
\hline & $\begin{array}{l}\text { Patients } \\
(n=45)\end{array}$ & $\begin{array}{l}\text { With depression } \\
\qquad(n=16)\end{array}$ & $\begin{array}{l}\text { Without depression } \\
\qquad(n=29)\end{array}$ & $\mathrm{p}$ \\
\hline Age in the evaluation (years) & $\begin{array}{c}45.56 \pm 7.31 \\
(31-67)\end{array}$ & $\begin{array}{c}46.19 \pm 8.36 \\
(36-67)\end{array}$ & $\begin{array}{c}45.21 \pm 6.79 \\
(31-59)\end{array}$ & $<0.34$ \\
\hline Sex & & & & $<0.76$ \\
\hline Male & 28 & 10 & 18 & \\
\hline Female & 17 & 6 & 11 & \\
\hline Level of education (years) & $\begin{array}{l}7.24 \pm 4.58 \\
(0-15)\end{array}$ & $\begin{array}{c}7.25 \pm 3.96 \\
(0-15)\end{array}$ & $\begin{array}{c}7.24 \pm 4.95 \\
(0-15)\end{array}$ & $<0.50$ \\
\hline MMSE & $\begin{array}{c}28.6 \pm 2.7 \\
(20-30)\end{array}$ & $\begin{array}{c}28.6 \pm 2.3 \\
(23-30)\end{array}$ & $\begin{array}{c}28.5 \pm 2.9 \\
(20-30)\end{array}$ & $<0.43$ \\
\hline Clinical form at the time & & & & $<0.17$ \\
\hline Akinetic-rigid & 23 & 6 & 17 & \\
\hline Rigidity-bradykinesia-tremor & 22 & 10 & 12 & \\
\hline Disease duration (years) & $\begin{array}{c}8.9 \pm 6.2 \\
(1-25)\end{array}$ & $\begin{array}{c}10.2 \pm 7.6 \\
(1-25)\end{array}$ & $\begin{array}{c}8.1 \pm 5.3 \\
(1-22)\end{array}$ & $<0.17$ \\
\hline Follow-up period (years) & $\begin{array}{l}3.6 \pm 3.4 \\
(0.5-15)\end{array}$ & $\begin{array}{l}4.6 \pm 3.2 \\
(0.5-11)\end{array}$ & $\begin{array}{l}3.1 \pm 3.6 \\
(0.5-15)\end{array}$ & $<0.14$ \\
\hline
\end{tabular}

MMSE, Mini Mental State Examination.

dementia were 13 for illiterate patients, 18 for patients who had from 1 to 8 years of schooling and 26 for patients with more than 8 years ${ }^{21}$. The severity of PD was quantified using the Hoehn-Yahr scales, the Unified Parkinson Disease Rating Scale (UPDRS) motor examination and the Schwab and England activities of daily living ${ }^{22}$. Patients were examined between August 2002 and March 2004. Some patients were examined twice or more; the worst score was always chosen for analysis. The study was approved by the Ethics Committee of the Hospital de Clínicas, Federal University of Paraná. Forty-five patients were found to fulfill the above criteria, and their clinical and epidemiological characteristics are shown in Tables 1 and 2.

The patients were divided into two groups after assessment: Group 1, which consisted of cases with depression, and Group 2, those without depression.

For statistical analysis we used the Student one-sided ' $\mathrm{t}$ ' test, the Mann-Whitney and Pearson and Spearman tests, the chi-squared test with Yates correction and the Fisher test.

\section{RESULTS}

Of the 45 patients that fulfilled the criteria, 16 $(35.6 \%)$ were found to have depression and 29 $(64.4 \%)$ not to have depression. These patients without depression were used as a control group. The average score on the Hamilton scale for the 16 depressed patients was $13.1 \pm 6.2$. Eight (50\%) of these had mild depression, 4 (25\%) moderate depression and $4(25 \%)$ were in remission; no patients presented severe depression. Of the 17 items on the Hamilton scale, those with scores greater than $50 \%$ were mood, work and activities, motor delay, psychic anx- iety, terminal insomnia, general somatic symptoms, somatic anxiety, middle insomnia and initial insomnia. The greatest score in relation to the maximum possible score, which represents the greatest severity, was for the item work and activities followed by initial and middle insomnia and general somatic symptoms (Table 1). There was no difference between the averages on the Hamilton scale for the 10 patients $(62.5 \%)$ who were having treatment for depression $(12.2 \pm 6.2)$ and the $6(37.5 \%)$ who were not $(14.5 \pm 6.6)(p<0.25)$. There was a correlation between the Hamilton scale and total duration of the disease $(r=0.46, p<0.05)$, use of levodopa $(r=0.39, p<0.05)$, levodopa dose $(r=0.31, p<0.05)$, UPDRS $(r=0.43, p<0.05)$, Hoehn-Yahr $(r=0.45, p<0.05)$ and the Schwab-England scale $(r=-0.59, p<0.01)$ in both groups.

The male sex predominated in both groups; however, average age, level of education, MMSE, proportion of the akinetic-rigid form and the classic symptomatic triad (tremor, rigidity and bradykinesia), duration of the disease and the length of time for which the patients were followed up during assessment were similar in both groups and showed no statistical difference (Table 2). Age at onset, initial clinical form, side on which symptoms started, dystonia during the early stages of the disease, history of smoking, life in a rural environment, exposure to herbicides or pesticides, ingestion of well water and a family history of PD were all similar in the groups with and without depression (Table 3).

The average severity on the Hoehn-Yahr scale and 
Table 3. Clinical and epidemiological characteristics at disease onset in 45 patients with early-onset Parkinson's disease.

\begin{tabular}{|c|c|c|c|c|}
\hline & $\begin{array}{l}\text { Patients } \\
(n=45)\end{array}$ & $\begin{array}{l}\text { With depression } \\
\qquad(n=16)\end{array}$ & $\begin{array}{l}\text { Without depression } \\
\qquad(n=29)\end{array}$ & $p$ \\
\hline Age/onset (years) & $\begin{array}{c}36.67 \pm 5.82 \\
(19-45)\end{array}$ & $\begin{array}{c}35.94 \pm 6.69 \\
(19-44)\end{array}$ & $\begin{array}{c}37.07 \pm 5.37 \\
(28-45)\end{array}$ & $<0.28$ \\
\hline Initial clinical form & & & & $<0.17$ \\
\hline Akinetic rigidity & 26 & 9 & 17 & \\
\hline Tremor & 14 & 4 & 10 & \\
\hline Postural instability & 5 & 3 & 2 & \\
\hline Side of the body at onset & & & & $<0.70$ \\
\hline right & 27 & 9 & 18 & \\
\hline left & 18 & 7 & 11 & \\
\hline Initial dystonia & 12 & 5 & 7 & $<0.62$ \\
\hline History of PD in other family members & 5 & 1 & 4 & $<0.43$ \\
\hline Smoking & & & & $<0.52$ \\
\hline Yes & 17 & 7 & 10 & \\
\hline No & 28 & 9 & 19 & \\
\hline Rural environment & & & & $<0.13$ \\
\hline Yes & 30 & 13 & 17 & \\
\hline No & 15 & 3 & 12 & \\
\hline Exposure to herbicides or pesticides & & & & $<0.97$ \\
\hline Yes & 7 & 3 & 4 & \\
\hline No & 38 & 13 & 25 & \\
\hline Ingestion of well water & & & & $<0.96$ \\
\hline Yes & 36 & 15 & 21 & \\
\hline No & 9 & 1 & 8 & \\
\hline
\end{tabular}

Table 4. Treatment, complications and severity indices in 45 patients with early-onset Parkinson's disease.

\begin{tabular}{|c|c|c|c|c|}
\hline & $\begin{array}{l}\text { Patients } \\
(n=45)\end{array}$ & $\begin{array}{l}\text { With depression } \\
\qquad(n=16)\end{array}$ & $\begin{array}{l}\text { Without depression } \\
\qquad(n=29)\end{array}$ & $\mathrm{p}$ \\
\hline $\begin{array}{l}\text { Average daily levodopa } \\
\text { dose }(\mathrm{mg})\end{array}$ & $\begin{array}{c}393 \pm 337 \\
(200-1000)\end{array}$ & $\begin{array}{c}434 \pm 346 \\
(200-1000)\end{array}$ & $\begin{array}{l}397.5 \pm 331 \\
(200-1000)\end{array}$ & $<0.28$ \\
\hline $\begin{array}{l}\text { Complications/levodopa (n) } \\
\text { Yes } \\
\text { No }\end{array}$ & $\begin{array}{c}22 \\
8\end{array}$ & $\begin{array}{c}10 \\
6\end{array}$ & $\begin{array}{c}12 \\
2\end{array}$ & $<0.17$ \\
\hline $\begin{array}{l}\text { Disease duration at onset of } \\
\text { complications (years) }\end{array}$ & $\begin{array}{c}7 \pm 3 \\
(2-14)\end{array}$ & $\begin{array}{l}6.3 \pm 2.2 \\
(3.5-9)\end{array}$ & $\begin{array}{l}7.5 \pm 3.5 \\
(2-14)\end{array}$ & $<0.19$ \\
\hline $\begin{array}{l}\text { Duration of levodopa at onset } \\
\text { of complications (years) }\end{array}$ & $\begin{array}{l}4.6 \pm 2.3 \\
(1.5-10)\end{array}$ & $\begin{array}{l}3.6 \pm 1.5 \\
(1.5-5)\end{array}$ & $\begin{array}{l}5.1 \pm 2.6 \\
(1.5-10)\end{array}$ & $<0.06$ \\
\hline Surgical treatment & 11 & 6 & 5 & $<0.76$ \\
\hline Hoehn-Yahr Staging Scale & $\begin{array}{c}2.4 \pm 0.9 \\
(1-5)\end{array}$ & $\begin{array}{l}2.65 \pm 0.94 \\
(1-4)\end{array}$ & $\begin{array}{l}2.25 \pm 0.80 \\
\quad(1-5)\end{array}$ & $<0.08$ \\
\hline UPDRS/ motor scale & $\begin{array}{l}21.4 \pm 9.06 \\
(7-46)\end{array}$ & $\begin{array}{c}24.1 \pm 11.2 \\
(7-46)\end{array}$ & $\begin{array}{l}19.6 \pm 7.46 \\
(8-40)\end{array}$ & $<0.07$ \\
\hline Schwab-England scale & $\begin{array}{c}78 \% \pm 18.11 \\
(20-100)\end{array}$ & $\begin{array}{c}71 \% \pm 24.28 \\
(20-100)\end{array}$ & $\begin{array}{l}83 \% \pm 25 \\
(30-100)\end{array}$ & $<0.10$ \\
\hline
\end{tabular}

UPDRS, Unified Parkinson's Disease Rating Scale.

the UPDRS motor scale was greater in the group with depression and showed a slight, but at non insignificant, statistical level. The Schwab-England scale was greater in the group without depression, but was not statistically significant either (Table 4).

No statistically significant difference was found 
between the groups in terms of daily dose of levodopa, levodopa-related complications or duration of the disease before the onset of complications; there was, however, a slight statistical trend for duration of levodopa use until the onset of complications. The number of patients submitted to surgical treatment in the groups with and without depression was similar. (Table 4). There was a correlation between the duration of the disease and the daily living scale in the group with depression $(r=-0.49, p<0.056)$ and without depression $(r=-0.42, p<0.02)$; between the duration and the severity of the disease measured on the $\mathrm{H}-\mathrm{Y}$ scale in the group with depression $(r=0.66$, $p<0.05)$ and without depression $(r=0.64, p<0.05)$; and between the duration of the disease and the levodopa dose in patients with depression $(r=0.50$, $p<0.05)$ and without depression $(r=0.73, p<0.05)$.

\section{DISCUSSION}

The frequency of depression in early-onset PD in our study was greater than in the population at large, in which prevalence is between $5.4 \%$ and $8.9 \%^{23}$. It was similar, however, to that found in studies which included all patients with PD, irrespective of age at onset $^{12,24}$. The frequency of major depression has been estimated to vary between 2.7 and $70 \%$ of all patients with PD, with an average around $40 \%$. This large disparity is probably due to differences in the methodology used to diagnose depression ${ }^{16}$. Various authors have suggested that the frequency of depression in EOPD is higher than in patients with late-onset $P{ }^{11}$. These results were not reproduced in our study. The findings derived from our cases agree with those of studies which showed that most patients present a clinical picture of mild depression ${ }^{24}$. Not all of the patients with depression were being treated with medication, showing that depression among our patients is also often underdiagnosed and untreated ${ }^{13}$. Identification of depression in patients with PD is made difficult by the overlap of the clinical symptoms of the two diseases. This raises questions as to whether existing scales for diagnosing and assessing the severity of depression are appropriate in patients with PD ${ }^{12}$. This difficulty was confirmed during routine patient visits to neurologists, who failed to identify depression in over half of the $44 \%$ of patients with PD who were depressed ${ }^{13}$. Both depression and anxiety can precede the onset of motor symptoms by many years; this happens in approximately $25 \%$ of depressed parkinsonians ${ }^{25}$.

Although we found a positive correlation between the duration of the disease and both the para- meters that measure the severity of the disease (Hoehn-Yahr and activities of daily living scales) and the daily levodopa dose, there was not a greater frequency of depression in more severe or longer-duration cases. This finding was unexpected since EOPD affects individuals during what is still a very productive period of life. These patients more commonly experience loss of employment, a breakdown in family relations and a greater degree of stigmatization ${ }^{10}$.

The risk factors for depression in patients with PD are the same as those for depression in the population at large, and the only specific marker for depression in PD was onset of symptoms on the right side of the body ${ }^{26}$. The interaction between depression and PD is bidirectional: depression is a risk factor for $P D$ and PD is a risk factor for depression ${ }^{27}$. In another study, depression was more frequent in patients with the akinetic form of the disease, and axial signs (postural instability and axial rigidity) were more significant in depressed patients, suggesting an association between depression and nondopaminergic lesions in $\mathrm{PD}^{28}$. There were no statistical differences in our study between the two groups in terms of sex, age at onset, side of the body where the first symptoms appeared, levodopa dose, presence of levodopa therapy complications or whether stereotaxic surgery had been carried out. Our finding that there is no relationship between levodopa therapy and depression agrees with previous findings, thus reaffirming the hypothesis of nondopaminergic mechanisms in parkinsonian depression ${ }^{29}$. The clinical manifestations that differentiate between EOPD and late-onset PD, namely the presence of dystonia at onset of the disease, the predominance of the akinetic-rigid clinical form and the shorter latency period for the appearance of levodopa-related complications ${ }^{9}$, were also similar in both groups in the study.

The fact that we did not find any statistical differences in scores for the severity of PD between the groups with and without depression, together with the fact that the frequency of depression in PD is greater than in both the population at large and patients suffering from other diseases that inflict the same degree of disability ${ }^{15}$, suggest that the reactive or external factor is not as important as the biological factor resulting from neuronal lesion in the pathogenesis of depression in PD.

None of the patients in the study who suffered from EOPD had a diagnosis of dementia, and the scores for MMSE and level of education were the same for the groups with and without depression. 
The low average age and short average total disease duration may have been contributing factors in the absence of dementia among our patients compared with other studies that used older patients with longer disease duration'. Even in the absence of dementia or depression, patients with advanced PD have a propensity to present clinically significant impairment in neuropsychological assessments that are consistent with changes in the prefrontal regions involved in the nigra-thalamo-cortical circuits ${ }^{28,30}$. Depression and dementia appear to be independent predictive factors for mortality ${ }^{31}$.

Parkin gene mutations are reported to be a major cause of early-onset parkinsonism (age at onset $<45$ years) in families with autosomal recessive inheritance and in isolated juvenile-onset parkinsonism (age at onset $<20$ years). The frequency of the parkin mutations in the patients with PD decreased with increasing age of onset ${ }^{6}$. In the other hand some epidemiological studies indicate a complex interaction between genetic vulnerability and environmental factors in patients with early-onset parkinsonism ${ }^{32}$. The incidence of PD in family members of $11 \%$ of our patients corroborates the finding that the younger the age at onset, the greater the chance of other family members suffering from $\mathrm{PD}^{3}$.

In short, the incidence of depression observed in EOPD patients in our study was greater than that of the population at large, although similar to figures reported in studies of patients with late-onset PD, and had no relationship with any clinical characteristic of the disease. EOPD patients with depression, however, presented earlier levodopa-related complications and were more affected on the Hoehn-Yahr, UPDRS and Schwab-England scales. Further studies with a larger number of patients with early-onset Parkinson's disease are needed to clarify these issues.

Acknowledgment - The authors thank to Mr. Colin Bowles for reviewing the manuscript.

\section{REFERENCES}

1. De Rijk MC, Tzourio C, Breteler MMB, et al. Prevalence of parkinsonism and Parkinson's disease in Europe: the EUROPARKINSON Collaborative Study. J Neurol Neurosurg Psychiatry 1997;62:10-15.

2. Gershanik OS, Nygaard TG. Parkinson's disease beginning before age 40. In Streifler MB, Korczyn AD, Melamed E, Youdim MBH (eds). Advances in neurology Vol.53. New York: Raven Press,1990:251-258.

3. Andrade LA. Early onset Parkinson's disease: critical review of the literature. Arq Neuropsiquiatr 1996;54:691-704.

4. Quinn N, Critchley P, Marsden CD. Young onset Parkinson's disease. Mov Disord 1987;2:73-91.

5. Gershanik OS, Leist A. Juvenile onset Parkinson's disease. In Yahr MD, Bergmann KJ (eds). Advances in neurology Vol 45. New York: Raven Press, 1986:213-216.
6. Periquet M, Latouche M, Lohmann E, et al. Parkin mutations are frequent with isolated early-onset parkinsonism. Brain 2003;126:12711278.

7. Bonifati V, Rohé CF, Breedveld GJ, et al. Early-onset parkinsonism associated with PINK1 mutations: frequency, genotypes, and phenotypes. Neurology 2005;65:87-95.

8. Friedman A. Old-onset Parkinson's disease compared with youngonset disease:clinical differences and similarities. Acta Neurol Scand 1994;89:258-261.

9. Schrag A, Bem Shlomo Y, Brown R, Marsden CD, Quinn N. Youngonset Parkinson's disease revisited-clinical features, natural history, and mortality. Mov Disord 1988;13:885-894.

10. Schrag A, Hovris A, Morley D,Quinn N, Jahanshahi M. Young versus older-onset Parkinson's disease: impact of disease and psychosocial consequences. Mov Disord 2003;18:1250-1256.

11. Kostic VS, Filipovic SR, Lesic D, Moncilovic D, Sokic D, Sternic N. Effects of age in Parkinson's disease. J Neurol Neurosurg Psychiatry 1994;57:1265-1267.

12. Lemke MR, Fuchs G, Gemende I, et al. Depression and Parkinson's disease. J Neurol 2004;251(Suppl 6):S24-S27.

13. Schulman LM, Taback RL, Rabinstein AA, Weiner WJ. Non-recognition of depression and other non-motor symptoms in Parkinson's disease. Parkinsonism Related Disord 2002;8:193-197.

14. Zgaljardic DJ, Foldi NS, Borod JC. Cognitive and behavior dysfunction in Parkinson's disease:neurochemical and clinicopathological contribuitions. J Neural Transm 2004;111:1287-1301.

15. Nilson FM, Kessing LV, Moller Sorensen T, Kragh-Andersen T, Bolwig TG. Major depressive disorders in Parkinson's disease: a register-based study. Acta Psychiatr Scand 2002;106:202-211.

16. Burn DJ. Beyond the iron mask: toward better recognition and treatment of depression associated with Parkinson's disease. Mov Disord 2002;17:445-454.

17. Ward CD, Gibb WR. Research criteria for Parkinson's disease. In Streifler MB, Korczyn AD, Melamed E, Youdim MBH (eds). Advances in neurology Vol 53. New York: Raven Press, 1990:245-249.

18. American Psychiatric Association: Diagnostic and Statistical Manual of Mental Disorder, $4^{\text {th }}$ Edition, Washington, DC, American Psychiatric Association, 1994.

19. Hamilton M. A Rating Scale for Depression. J Neurol, Neurosurg Psychiatry 1960;23:56-62.

20. Folstein MF, Folstein SE, McHugh PR. "Mini-mental state": a practical method for grading the mental state of patients for the clinician. J Psychiatr Res 1975;12:189-198.

21. Bertolucci PHF, Brucki SMD, Campacci SR, Juliano Y. O mini-exame do estado mental em uma população geral-impacto da escolaridade. Arq Neuropsiquiatr 1994;2:1-7.

22. Horta W. Escalas Clínicas para Avaliação de Pacientes com Doença de Parkinson. In: Meneses MS, Teive HAG (eds). Doença de Parkinson. Rio de Janeiro: Guanabara-Koogan, 2003:153-162.

23. Mann JJ. The medical management of depression. N Engl J Med 2005; 353:1819-1834.

24. Prado RCP, Barbosa ER. Depression in Parkinson's disease: study of 60 cases. Arq Neuropsiquiatr 2005;63:766-771.

25. Burn DJ. Depression in Parkinson's disease. Eur J Neurol 2002;9(Supp 3):S44-S54.

26. Leentjens AF, Lousberg R, Verhey FR. Markers of depression in Parkinson's disease. Acta Psychiatr Scand 2002;106:196-201.

27. Silberman CD, Laks J, Rodrigues CS, Engelhardt E. Review of depression as a risk factor in Parkinson's disease and the impact on cognition. Rev Psiquiat Rio Grande do Sul 2004;26:52-60.

28. Auguenot A, Loll PY, Nean JP, Ingrand P, Gil R. Depression and Parkinson's disease: study of a series of 135 Parkinson's patients. Can J Neurol Sci 2002;29:139-146.

29. Choi C, Sohn YH, Lee JH, Kim J. The effect of long term levodopa therapy on depression level in de novo patients with Parkinson's disease. J Neurol Sci 200;172:12-16.

30. Green J, McDonald WM, Vitek JL, et al. Cognitive impairments in advanced PD without dementia. Neurology 2002;59:1320-1324.

31. Hughes TA, Ross HF, Mindman RH, Spokes EGS. Mortality in Parkinson's disease and its association with dementia and depression. Acta Neurol Scand 2004;110:118-123.

32. DeLong MR, Juncos JL. Parkinson's disease and other movement disorders. In Kasper DL, Braunwald E, Fauci AS, Hauser SL, Longo DL, Jameson JL (eds). Harrison's principles of internal medicine. New York: McGraw Hill, 2005: 2406-2418. 